\title{
Perception on Cultural Diversity and Multiculturalism Education
}

\author{
Heri Susanto \\ History Education Department \\ Faculty of Teaching and Education \\ Universitas Lambung Mangkurat \\ Banjarmasin, Indonesia
}

\begin{abstract}
Multiculturalism education is an old concept that always reappears when diversity issues encounter challenges related to the condition of Indonesian nation experiencing disintegrating symptoms. Multiculturalism education needs attention, especially with the development of society as a result of the development of global trends that indirectly often lead this nation into the tendency of uniformity and marginalize cultural diversity in each region. Cultural diversity is the core of multiculturalism, so building the concept of multiculturalism education should start from building positive perceptions on the nation's cultural diversity. Conceptually positive perceptions on cultural diversity refers to the ability of each nation's elements to interpret the plural and heterogeneous conditions of the nation's cultural elements into educational values that are in line with the principle of diversity.
\end{abstract}

Keywords - cultural diversity, multiculturalism, education

\section{INTRODUCTION}

Traditional games nowadays have been displaced by the rapid development and advancement of technology that creates digital-based games. Games have replaced the traditional game that is identical to the values of life, such as the value of sportsmanship, competitive value, and the value of cooperation.

Multiculturalism is both a feature and an indentity of Indonesia. The condition of Indonesia as a country with diverse tribes, religions, languages and various indicators that portray the diversity of its people is both potential and threatening. The condition is considered a potential if it is successfully utilized wisely as a strengthening of identity and wealth of the nation. However, it can be a threat if it is managed improperly which might create conflict. Ref [1] in his review mentions that there is actually not a single place in the world - except perhaps Central Asia - which, like the archipelago, places the presence of almost every major world culture, side by side or melting into one.

Based on geographical, cultural and ethnic reality, this archipelago is inhabited by hundreds of tribes with diverse cultures and different religions as well as believes. This fact encourages the pioneers of independence in the era of idealization of the struggle to understand that the nation is a group of people who have the same historical background, fate, goals and ideals. This formulation unites all the tribes in Indonesia as a nation. This is indeed also the formula that empirically managed to bring the Indonesian nation to the gate of independence.

Indonesian nationalism is formed amid the cultural diversity of each region, so it can not be denied that the culture of Indonesia is essentially a manifestation of the local cultures themselves. A correct perception of cultural diversity will be able to direct every society in the region to have a strong identity and character as an Indonesian people in the framework of multiculturalism. In addition to this, the history of many major countries proves that a nation that is able to develop into a nation of competitors in the world is a nation that has a strong cultural identity and is able to maintain the noble roots of their culture [2].

Based on these conditions, the values of multiculturalism should be embodied in the practice of education. Multiculturalism education is not a new issue, but it has not been structured in the curriculum or educational goals. If we examine carefully, the essence of multiculturalism is a condition of cultural diversity, so multicultural education should start from the effort to build a positive perception on the nation's cultural diversity and convey it in educational praxis.

\section{METHOD}

The role of culture in the reform era faces challenges related to its function as the way to increase awareness of "sense of belonging and nationalism" [3]. The values contained in the regional culture is expected to make the character of society in each region stronger and more advanced in the frame of the Unitary State of the Republic of Indonesia, not just a tool of disunity among fellow citizens. A systematic awareness efforts through the world of education is definitely needed to realize it.

One of the themes that can be raised to shape positive perceptions of cultural diversity is to raise awareness of the importance of respecting the nation's culture in the local scope which ultimately has implications for positive perceptions on the nation's cultural diversity. This departs from the assumption that the culture of the nation is essentially a unity or symbolization of the local cultures of the Indonesian nation. 
In the context of Indonesia, cultural diversity is not only seen in national coverage, but it is also closely related to cultural diversity in the local environment.

The localization is lexically closer to the geographical concept. In the concept of culture, localization should be understood that it does not specifically refer to an ethnic group. When viewed from the history of the Indonesian nation, the localization shows the uniqueness of the process of struggle, the life and development of a community in an area that may be composed of more than one particular ethnic group. Thus, the localization in the concept of history refers to the peculiarities of the values of struggle and life processes of a society in an area within a certain time [2].

Perception is a psychological aspect that will greatly affect one's actions towards something. [4] describes the ability to do exactly between two or more stimuli, based on the distinction between the distinctive physical features of each stimulus. The existence of this ability in a reaction shows awareness of the presence of stimuli and the difference between all the stimuli that exist. Reaction that arise, for example, is the existence of a good or bad stereotype to the perceived object.

Furthermore, [5] explain that perception is a relatively rational process in taking information about something and organizing it based on certain principles. Perception through interactions include heuristic information processing.

Interpretation is inseparable from perception since perception always starts from the process of sensation and leads to the interpretation of the object of perception. Ref [6] explains that perception as the focus of the study based on the assumption of perception is the core of communication, whereas interpretation is the core of perception. In relation to culture, perception on culture is an attempt to obtain information through interactions involving communication and contact with perceived culture and then heuristic information processing to understand the object of perception and interpret it according to the understood principles.

If social perception is a process by which one understands others, perception of culture is a process of one's understanding of culture. In this process, attribution occurs, namely the attempt to understand the causes behind sociocultural behavior that plays an important role to understand the perceived object [7].

The attribution process can also be biased since the attribution process is also influenced by one's emotional factors that tend to change easily [5]. Based on the point, it can be argued that in the perception the stimulus is the same. However, since experience is not the same, the ability to think and the frame of reference are not the same either, and in turn the possibility of perception results between individuals with each other is not the same either [8].

In terms of perceptions on culture, sometimes when the perception involves a group of people, it can lead to false consensus [5], namely the tendency to overestimate the prevalence and attempt to generalize the perceived object. A good view from someone who is influential in the group will often be followed by other group members. There can also be one who is considered good, so others in the same group are also considered good.

When associated with culture, cultural perception is an awareness of the existence of culture as a result of taking information about culture and organizing it based on certain principles. The result of this organization will create the interpretation on the culture and the basis of action for the individual or society.

\section{RESUlt AND DISCUSSION}

\section{A. Multiculturalism Education Through Perception On Cultural Diversity}

According to anthropology, culture is "the whole system of ideas, actions and the work of human beings in the framework of the life of society which belong to human by learning" [9]. In the meantime Ralph Linton argues that culture is the configuration of behavior consisting of constituent elements that are supported and transmitted by members of a particular society. Meanwhile C. Kluckhohn and W.H. Kelly formulates that culture is the pattern of life created in history, which is explicit, implicit, rational, irrational and non-rational, contained at all times as a potential guide to human behavior [10].

The term of culture is derived from Sanskrit and Malay, namely budhi and daya. Budhi refer to logical mind, while daya refers to words. Malay is the power of influence and strength. Accordingly, in brief it may refer to the power of thinking, soul and willingness to move the soul. ... In brief, it is a way of life conducted by a group of people comprises social, politic, economic, religion, belief, custom, attitude, and value [11].

Based on the definition that culture cannot be separated from human life, humans form a culture and at the same time humans are also shaped by the culture that surrounds them. Whereas in Linton's definition culture is supported and forwarded by members of society, then culture is the identity of a society and developed by the community itself. In accordance with the dynamic character of a society, to face all the challenges that come, the culture also always experiences reinterpretation and transformation so that culture is not something static, but very dynamic to follow the movement of its community.

It is an absolute reality that Indonesia is a country with many cultures and this uniqueness in addition to wealth is also a challenge to our national identity. The difficulty of forming a common perception of the nation's cultural identity is one of the main problems faced by countries with many cultures. Tribal fanaticism and stereotypical perceptions of other cultures are other problems that also often arise in the social intercourse with a strong plural feature like Indonesia.

The historical approach to Indonesian society - most of which is the current constituent of the Indonesian nation - can provide a logical understanding of the plural and heterogeneous conditions of this society. History records that the Archipelago that has now become the territory of the State of the Republic of Indonesia has experienced the arrival of 
people - who are not only different in ethnic dimension but also race - from some parts of the world. The human groups have certainly played a major role in asserting that Indonesia is a plural and heterogeneous country in the field of culture [12].

Pluralism leads to the so-called awareness of others' existence and the difference in both real life and philosophical life with its representation [13]. This awareness stems from a positive perception on cultural diversity.

On the other hand, when world cultural pluralism provides an opportunity for developing countries to "be different", it should be interpreted as an opportunity to explore unique "local" cultures that can help achieve national interests in international politics [14].

Perceptions on culture that lead to cultural awareness begin from the following points; First, it begins from knowledge of the existence of various ethnic cultures with its own identity and its advantages. Second, it moves to an open attitude to respect and seek to understand the culture of ethnic groups outside the tribe of its own people, in other words the willingness to know each other. Third, the perception might begin from knowledge of various cultural developments in various stages in the past. Fourth, the perception might be affected by the notion that in addition to caring for and developing elements of cultural heritage, we as a united Indonesian nation are developing a new culture, namely the national culture.

The diverse circumstances - besides unavoidable undeniably have positive and negative dimensions. In recent years, approximately towards the end of the twentieth century, a multiculturalism has developed that essentially seeks to bridge the plural and heterogeneous conditions in order to bring about a directional twist that ultimately leads to the courage to unite in diversity, rather than unified in uniformity. According to multiculturalism, there must be an empirical reality of diversity and difference, but at the same time there should be equality, tolerance, respect for democracy, human rights and solidarity [15].

The establishment of a strong Indonesian multicultural society cannot be taken for granted or through trial and error. Instead, it must be pursued systematically, programatically, using integrated and sustainable effort, and even it needs acceleration. One of the important strategies in accelerating it is multicultural education organized through all educational institutions, both formal and non formal, and even informal in the wider community [16].

Multiculturalism education is essentially a systematic effort to instill multicultural values and form citizens into multicultural people. In terms of education, in essence education is a process of continuous and systematic culturalization that will form the learner's personality into a complete adult human. In this case, education and culture are two things that cannot be separated. Culture of a society will affect the process of personality formation of an individual in education. In this concept, education is not only identified as school activities, but also the process of culture in the family and society. In this regard, it is important to re-explore the positive values of diversity in the educational process as a method of inculcating the noble values of tradition that will shape the individual character of learner.

Furthermore [17] describes that multicultural education has five interrelated dimensions and can be a guide in the implementation of learning, namely:

a. Dimension of content integration. This dimension emphasizes the integration of multiculturalism-laden material that can be key points for providing quality information to learners. At this level, teachers should be able to develop the curriculum to include the content of multiculturalism material.

b. The dimension of knowledge construction. This dimension rests on students' understanding of multiculturalism. The formation of the knowledge structure of multiculturalism becomes an emphasis in this dimension.

c. Prejudice reduction dimension. In this dimension the formation of positive perceptions of cultural diversity becomes very important. Through positive perceptions on cultural diversity, learners will avoid stereotypes against other cultures.

d. Equitable pedagogy dimensions. Technically this dimension leads learners to innovate with various methods or learning models. Cooperative learning model or collaborative learning model is an alternative that can be selected to achieve this dimension.

e. Dimensions of school culture empowerment and social structure. The school culture in this dimension is the elements of the socio-cultural dimension developed in the interaction patterns of learning and social values developed in the school environment.

The five dimensions show the interconnectedness and mutual support in the formation of perceptions. Figure 1 illustrates the five dimensions:

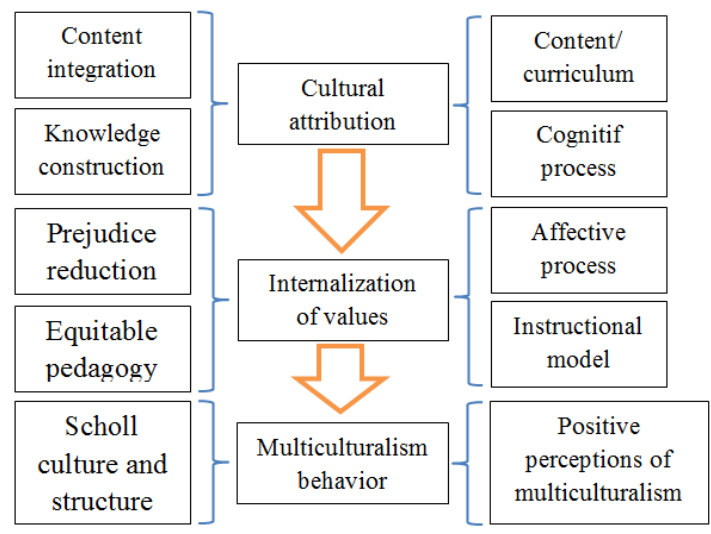

Fig 1. Concept of Multiculturalism Education

Figure 1 is the structure of the concept of multiculturalism education through the establishment of positive perceptions on cultural diversity. Multiculturalism education begins with the integration of multiculturalism material that is done through the development of the curriculum, and it is continued to the formation of knowledge construction through cognitive processes. Both stages are the process of attribution in the formation of perception. In the next stage through the affective 
process, the reduction of cultural prejudices are carried out and operationally translated in the interaction of learning between teachers with students and students with students. This process is reinforced by using a learning model that supports the process of internalizing the value of multiculturalism. The final stage of this process is the establishment of multiculturalism behavior through school culture that reflects positive perceptions of cultural diversity.

In a simple way these efforts can be done by fostering positive perceptions on cultural diversity. This is important because the core of multicultural society is the willingness to accept and appreciate other cultures that are reflected in the perception on cultural diversity.

The problem of multiculturalism can be explained by the fact that every citizen is not abstract individual who is deprived of their social roots. The recognition of the cultural rights of ethnic groups, especially the minority, must first be opened as a precondition to the formation of individual citizens who can transcend their ethnic identity [18].

The perception of a multicultural culture characterized by multiculturalism is generally associated with the assumption that "every culture has a dominant personality type" [19]. This appears, for example, when we perceive that a person of a particular ethnic group tends to have certain behavioral characteristics in accordance with the dominant character of the original community.

Positive perceptions will arise when the perceived object has a tendency to be equal or at least not contrary to the understanding of the perceptor. Conversely, if the object of perception has many differences, especially very contrary to the cultural values adopted and understood by the perceptor, it will cause a negative perception. If positive perceptions will lead to integration, negative perceptions will lead to disintegration.

Within the framework of the Unitary State of the Republic of Indonesia, it is very likely that misunderstandings arise as a result of the diversity of existing differences. Thus, to form a positive perception on diversity there needs to be understanding of diversity principles as the spirit of Indonesian national integration. The principles of diversity are the acceptance and mutual respect for the diversity of the nation that include the diversity of race, ethnic, linguistic, cultural, social, economic, political and religious.

It can be concluded that multiculturalism is a place of learning of people from different cultures, through communication processes, social behavior, mutual norms and values, and institutional structures. Multiculturalism is a process of knowledge and experience transactions used by community members to interpret their different worldviews in the direction of cultural novelty [6]. With this paradigm it should be understood that cultural diversity in each region is an element that enriches the process of identity formation of Indonesia.

Thus, perceptions on cultural diversity are perceptions directed at the tendency to accept, understand and value diversity as an Indonesian national identity, with the following indicators: being aware of the cultural existence of each tribe as part of Indonesian culture, having sensitivity to the role of culture in shaping the character of its society, showing a sense of belonging to the culture of the nation, and interpreting the positive values of cultural diversity in the life of nation and state. The values will be transformed into education using the following steps: cultural attribution, internalization of value and multiculturalism behavior as described in Figure 1. Therefore, the development of the concept of multiculturalism education through the perception on cultural diversity can be actualized in education praxis.

\section{CONCLUSION}

Multicultural values should be manifested in educational practice. Multiculturalism education is not a new issue, but it has not been contained in the curriculum or educational goals. Multiculturalism education is essentially a systematic effort to instill multicultural values and help citizens to be multicultural people. Multiculturalism education begins with the integration of multicultural material through curriculum development, and the formation of knowledge construction through cognitive processes. Through the affective process, cultural bias reduction is operationally translated into the interaction of learning between teachers and students as well as students and their peers. This process is reinforced by using a learning model that supports the process of internalizing the value of multiculturalism. The final stage of this process is the establishment of multiculturalism behavior through school culture that reflects positive perceptions of cultural diversity.

\section{REFERENCES}

[1] Pérez-Lombard, Luis, José Ortiz, and Christine Pout, "A review on buildings energy consumption information," Energy and buildings 40, no. 3 (2008): 394-398.

[2] Soemitro, "Tantangan dan Peluang Wawasan Kebangsaan", dalam Pendidikan Wawasan Kebangsaan, Tantangan dan Dinamika Perjuangan Kaum Cendekiawan Indonesia, Jakarta: LPSP dan Gramedia Widiasarana Indonesia, 1994

[3] R.Wiriatmadja, "Menyegarkan Kembali Model Pendekatan Inquiri di Kalangan Pengajar Sejarah", dalam Pendidikan Sejarah di Indonesia Perspektif Lokal, Nasional, dan Global, Bandung: Historia Utama Press, 2002

[4] W.S. Winkel, Psikologi Pengajaran, Yogyakarta: Media Abadi, 2004

[5] S. Taylor, L.A Peplau, dan D.O Sears, Psikologi Sosial, Jakarta: Kencana, 2009

[6] A. Purwasito, Komunikasi Multikultural, Surakarta: Muhammadiyah University Press, 2003

[7] R.A Baron, dan D. Byrne, Psikologi Sosial, Jakarta: Erlangga, 2004

[8] B. Walgito, Psikologi Sosial Suatu Pengantar, Yogyakarta: Andi, 2003

[9] Koentjaraningrat, Pengantar Antropologi, Jakarta: UI Press, 1980

[10] Harsojo, Pengantar Antropologi, Bandung: Binacipta, 1967

[11] A.A. Seman,, "Multicultural and Ethnicity Approach in History Towards National Integration in Malaysia" dalam Historia: International Journal of History Education, Vol. XI, No. 2, Bandung: the Associatio of History Educators and Researchers, 2010

[12] I.G.S Astra, , "Pluralitas dan Heterogenitas dalam Konteks Pembinaan Kesatuan Bangsa” dalam Endang Sri Hardiati dan Rr, Triwurjani (edt.), Pentas Ilmu di Ranah Budaya, sembilan windu Prof. Dr. Edi Sedyawati. Denpasar: Pustaka Larasan, 2010

[13] S.R. Dzuhayatin, "Gender dan Pluralisme di Indonesia" dalam Robert W. Hefner (edt.): Politik Multikulturalisme, Yogyakarta: ImpulsKanisius, 2007 
[14] T. Warsito dan W. Kartikasari, Diplomasi Kebudayaan: Konsep dan Relevansi bagi Negara Berkembang; studi kasus Indonesia, Yogyakarta: Ombak, 2007

[15] E. Sedyawati, Budaya Indonesia: Kajian Arkeologi, Seni, dan Sejarah, Jakarta: Raja Grafindo Persada, 2006

[16] A. Azra, "Jati Diri Indonesia: Pancasila dan Multikulturalisme" dalam Jusuf Sutanto (edt.). The Dancing Leader, Hening-Mengalir-Bertindak, Jakarta: Kompas Media Nusantara, 2011

[17] J. Banks, Teaching Strategies For Ethnic Studies, Newton: Allyn and Bacon, 1984.

[18] Y. Latif, Negara Peripurna: Historisitas, Rasionalitas, dan Aktualitas Pancasila, Jakarta: Gramedia Pustaka Utama, 2011

[19] D. Kaplan, dan R.A. Manners, Teori Budaya, Yogyakarta: Pustaka Pelajar, 2002 